\title{
Estadios precoces de cancer oral: pronóstico en relación con gradación histológica, linfagiogénesis intratumoral y expresión de factor de crecimiento endotelial vascular Tipo-C (VEGF-C)
}

\author{
Early stage oral cancer: prognosis with regard to histological grading, intratumoral lymphangiogenesis, \\ and the expression of vascular endothelial growth factor-C (VECF-C)
}

Hemos leído con gran interés el estudio de Muñoz-Guerra y cols. sobre la evaluación de marcadores pronósticos de recidiva en carcinoma epidermoide intraoral T1-T2. En el artículo, los autores tratan la linfangiogénesis intratumoral (LI) y su identificación por medio de la tinción inmunohistoquímica de PA2.26, una glicoproteina transmembranaria que en un principio se identificó como un antígeno de superficie celular inducido durante la carcinogenesis epidermal y la remodelación cutánea. ${ }^{1}$ Los autores pudieron demostrar en un estudio previo, que pacientes con tumores LI+ mostraban una evolución menos favorable respecto al tiempo libre de enfermedad, al comparar éstos con los pacientes con tumores LI-, pero que LI no era un variable con influencia estadísticamente significativa en cuanto a supervivencia global. ${ }^{2}$ Los resultados del estudio actual demuestran una vez más que los pacientes con CEI con ausencia de LI, tuvieron mejor pronostico en cuanto a supervivencia y periodo libre de enfermedad, sin embargo la diferencia no era estadísticamente significativa.

A pesar de la aplicación y evaluación detallada de varios sistemas de gradación tumoral histológica que los autores emplean, no logran demostrar su utilidad clínica global.

Si aceptamos el supuesto de que los tumores contienen linfáticos de su propia creación, es decir, que linfangiogénesis ocurre dentro de neoplasmas malignos, la pregunta que nos deberíamos hacer es, ¿cómo se podría establecer que estas vías nuevas se intercomunican y que hay anastomosis con los sistemas linfáticos nativos? Los autores pudieron identificar linfáticos intratumorales mediante la inmunohistoquímica. Sin embargo, los 96 pacientes en el estudio eran pacientes N0. Dado que este estudio trata de evaluar $\mathrm{LI}+$ como un predictor de $\mathrm{pN}+$, la cohorte es inapropiada. Nos parece que sería más apropiado la selección de pacientes sometidos a la disección cervical electiva para intentar identificar la utilidad pronostica de IL+. Además, como hemos visto con anterioridad, el riesgo de metástasis oculta en CEI T1 y T2 oscila entre 7 y $41 \% .5,6$ Asimismo, la ausencia total de metástasis nodal en este grupo es un tanto inusual.

Otros marcadores moleculares demuestran un futuro prometedor parecido. Por ejemplo, Hassan y cols., comprobaron que el índice de recurrencia o metástasis de carcinoma epidermoide de cabeza y cuello era más elevado respecto a los tumores con sobreexpresión de ciclina B1, que para los tumores donde no se encontró. ${ }^{3}$ Hay datos recientes que indican que la activación de Akt fosforilado, una quinasa en la supervivencia celular, es un valor pronóstico significativo de un periodo corto de supervivencia libre de enfermedad en pacientes con carcinomas de la lengua, independientemente del estadio y la afectación nodal. ${ }^{8}$
We have read with great interest the study by MunozGuerra and colleagues regarding the evaluation of prognostic markers for recurrence in $T 1$ and $T 2$ oral squamous carcinomas. In their article, the authors discuss intratumoral lymphangiogenesis (IL) and the identification thereof, via immunohistochemical labeling of PA2.26, a transmembrane glycoprotein originally identified as a cell-surface antigen induced in epidermal carcinogenesis and skin remodeling. Previously, the authors were able to demonstrate that patients with IL+ tumors had a less favorable disease free pattern compared to those with IL- tumors, but that IL was not a statistically significant influential variable in overall survival. ${ }^{2}$ The results of the current study once again demonstrate that those patients with oral squamous cell carcinoma (OSCC) demonstrating IL-, showed a better prognosis in terms of both survival and disease free pattern, however the difference was not statistically significant.

In spite of the elaborate application and evaluation of various histological tumor grading schemes employed by the authors, they failed to demonstrate overall clinical utility.

If one accepts the supposition that tumors contain functional lymphatics of their own creation, that is to say that lymphangiogenesis occurs within malignant neoplasms, a question which comes to mind is, how does one establish that these new channels are interconnected and anastomose with native lymphatic networks? The authors were able to immunohistochemically identify intratumoral lymphatics, and yet all ninety-six patients in the current study were $\mathrm{NO}$. Given that the study at hand wishes to evaluate IL+ as a predictor of $p \mathrm{~N}+$, the cohort is inadequate. Selection of all patients undergoing elective neck dissection to attempt to identify the predictive value of IL+ would seem more appropriate. Furthermore, as it has been previously shown, the risk of occult metastases in T1 and T2 OSCC ranges between 7 and $41 \% .5,6$ Therefore, the complete absence of nodal metastases in this population is somewhat unusual.

Other molecular markers show similar promise. For instance, Hassan et al demonstrated head and neck squamous carcinomas with cyclin B1 overexpression more frequently had tumor recurrence or metastasis, as compared with those tumors without. ${ }^{3}$ Similarly, there are recent data to support that activation of phsphorylated-Akt, a kinase involved in cell survival, is a significant prognostic indicator of shorter disease-free survival in patients with tongue carcinoma, independent of stage and nodal status. ${ }^{8}$ 
Existe una clara necesidad de seguir buscando biomarcadores que predigan el comportamiento tumoral y la evolución del paciente. Esto representa mucho más que una ocupación académica, dado que prometedores epitopes nuevos aparecen continuamente, que algún día sean tal vez de utilidad clínica rutinaria. Animamos a los autores para que sigan con su trabajo, con seguimientos de una duración más larga, y que en investigaciones sucesivas evalúen pacientes con NO clínicos para determinar si LI+ está relacionado con la micrometastasis oculta. Asimismo, recomendamos un seguimiento continuado de los pacientes tratados de manera conservadora, es decir que no fueron sometidos a una disección electiva cervical, para determinar si LI+ estaba relacionado con el desarrollo posterior de metástasis ganglionar. Además de esto, la identificación y cuantificación de la presencia o ausencia de embolos tumorales podría ser útil, y se podría incorporar en futuros trabajos.

Jatin P. Shah

Jefe de Servicio. Servicio de Cirugía de Cabeza y Cuello Memorial Sloan-Kettering Cancer Centrer. New York, EE.UU.
Clearly there is a need for continued search for biomakers, predictive of tumor behavior and patient outcome. It is far more than just an academic pursuit, since promising novel epitopes are continuously surfacing, which may one day be of routine clinical utility. We encourage the authors to continue their work, with follow-up of longer duration, and in a subsequent investigation, evaluate patients that are clinically NO and determine whether IL+ correlates with occult micro-metastases. Similarly, continued monitoring of those patients treated conservatively, i.e., who did not undergo elective neck dissection, and determine if IL+ correlates with subsequent development of nodal metastases. Additionally, identification and quantification of the presence or absence of tumor emboli may be of value and could be incorporated into future work.

\section{Bibliografía}

1. Martin-Villar E, Scholl FG, Gamallo C, Yurrita MM, Munoz-Guerra M, Cruces J, Quintanilla M. Characterization of human PA2.26 antigen (T1 $\alpha-2$, podoplanin), a small membrane mucin induced in oral squamous cell carcinomas. Int / Cancer 2004;113:899-910.

2. Munoz-Guerra MF, Marazuela EG, Martin-Villar E, Quintailla M, Gamallo C. Prognostic significance of intratumoral lymphangionenesis in squamous cell carcinoma of the oral cavity. Cancer 2004;100:553-60.

3. Hassan KA, El-Naggar AK, Soria JC, Liu D, Hong WK, Mao L Clinical significance of cyclin B1 protein expression in squamous cell carcinoma of the tongue. Clin Cancer Res 2001;7:2458-62.

4. Scholl FG, Gamallo C, Vilaro S, Quintanilla M. Identification of PA2.26 antigen as a novel cell-surface mucin-type glycoprotein that induces plasma membrane extensions and increased motility in keratinocytes. / Cell Sci 1999;112:460113.

5. Shah JP. Head and Neck Surgery and Oncology. 3rd ed. Mosby, New York, 2003.

6. Sprano A, Weinstein G, Chalian A, Yodul M, Weber R. Multivariate predictors of occult neck metastasis in early oral tongue cancer. Otolayngol Head Neck Surg 2004;131:472-6.

7. Beasley NJP, Prevo R, Banerji S, Leek RD, Moore J, Van Trappen P, Cox G, Harris $\mathrm{AL}$, Jackson DG. Intratumoral lymphangiogenesis and lymph node metastasis in head and neck cancer. Cancer Research 2002;62:1315-20.

8. Massarelli E, Liu DD, Lee J), El-Naggar AK, Lo Muzio L, Staibano S, De Placido S, Myers JN, Papadimitrakopoulou VA. Akt activation correlates with adverse outcome in tongue cancer. Cancer 2005;104:2430-6. 